DOI: https://doi.org/10.34069/AI/2021.40.04.24

\title{
Forensic support for the international search
}

\section{Криміналістичне забезпечення міжнародного розшуку}

Received: April 12, 2021

\begin{abstract}
The purpose of the article is to formulate the basic theoretical principles and practical recommendations for forensic support for the international search. Subject of research: The subject of research is the concept, content, objectives and features of the implementation of forensic support for the international search. Methodology: In the course of the research general scientific methods, such as the methods of analysis and synthesis, induction and deduction, specification, summarization and analogy, etc. were used. Research results: According to the results of the research, it is substantiated that the international search is a complex legal institution and a separate form of international cooperation. Forensic support in this context is to create the conditions of preparedness and implementation of methods, tools, techniques of forensics in order to solve the problems of the international search. Practical consequences: It is proved that the international search is carried out according to certain stages, where certain measures of forensic support are necessary to be applied. Value / originality: Forensic support for the international search is to maximize the use of modern advances in science and technology to expand the range of sources of forensic information that can be applied in the
\end{abstract}

Accepted: May 9, 2021

Written by:
Humin Oleksii ${ }^{22}$
https://orcid.org/0000-0002-8016-945X
Nykyforchuk Dmytro ${ }^{93}$
https://orcid.org/0000-0001-9041-6197
Pavliuk Nataliia $^{94}$
https://orcid.org/0000-0002-5136-1450
Volobuieva Olena $^{95}$
https://orcid.org/0000-0002-8601-4344
Antoshchuk Andrii $^{96}$
https://orcid.org/0000-0002-5088-4372

\section{Анотація}

Метою статті $\epsilon$ формулювання основних теоретичних засад та практичних рекомендацій криміналістичного забезпечення міжнародного розшуку. Предмет дослідження: Предметом дослідження $є$ поняття, зміст, завдання та особливості реалізації криміналістичного забезпечення міжнародного розшуку. Методологія: У процесі дослідження були використані загальнонаукові методи, аналіз і синтез, індукція і дедукція, конкретизація, узагальнення та аналогія. Результати дослідження: За результатами проведених досліджень обгрунтовано, що міжнародний розшук $є$ комплексним правовим інститутом та окремою формою міжнародного співробітництва. Криміналістичне забезпечення за цих умов полягає у створенні умов готовності та реалізації методів, засобів, прийомів криміналістики 3 метою вирішення завдань міжнародного розшуку. Практичні наслідки: Доведено, що міжнародний розшук реалізується згідно певних етапів, на кожному 3 яких $\epsilon$ необхідність застосування тих чи інших заходів криміналістичного забезпечення. Цінність / оригінальність: Криміналістичне забезпечення міжнародного розшуку полягає у максимальному використанні сучасних досягнень науки i

\footnotetext{
92 Doctor of Law, Professor, Head of the Department of Criminal Law and Procedure of Lviv Polytechnic National University, Ukraine.

${ }^{93}$ Doctor of Law, Professor, Head of the Unit for the Organization of Scientific Activity and Protection of Intellectual Property Rights of the National Academy of Internal Affairs, Ukraine.

${ }^{94} \mathrm{PhD}$ in Law, Associate Professor of the Forensics (criminalistics) Department of Yaroslav Mudryi National Law University, Ukraine.

$95 \mathrm{PhD}$ in Law, Professor, Dean of the Faculty no. 1 of Donetsk Law Institute of the Ministry of Internal Affairs of Ukraine, Ukraine.

${ }^{96} \mathrm{PhD}$ in Law, Associate Professor of the Department of Criminology and Forensic Science of the National Academy of Internal Affairs, Ukraine.
} 


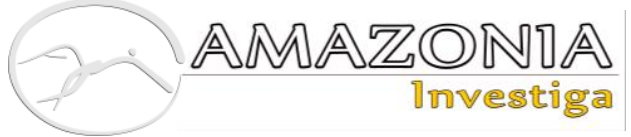 \\ international search.}

Key words: forensic support, international search, suspect, criminal offense.

\section{Introduction}

Globalization as a process that has been introduced in various areas of human life is also a prerequisite in the field of criminal science; because international crime has spread and no country is safe from some of the world's crimes (Khiyavi \& Shamloo, 2018, p. 215).

There is an increase in crime of international nature in modern society, and a tendency to the rise in the number of persons suspected (accused) of committing criminal offenses in foreign countries, trying to avoid responsibility, hiding in other countries. Therefore, the efforts of one or even several States to ensure proper counteraction to criminal acts are insufficient. One of the main methods to solve this problem is effective international cooperation in combating crime, including the implementation of coordinated activities of law enforcement agencies of different States and international organizations for the purpose of international investigation.

International cooperation plays an important role in strengthening and developing relations between States under modern conditions. Its impact on the protection of legitimate interests, rights and freedoms of the individual, society and the State, the strengthening of international law and order and the fight against crime is also significant.

The desire of each State to combat crime creates the basis for concluding relevant international agreements, in which special attention is paid to the actual international search and extradition of persons suspected (accused) of committing criminal offenses, hiding from the execution, as well as the application of other measures of international cooperation.

The analysis of the content of the main international documents devoted to the implementation of the international search shows that the problem of improving the efficiency of activities in this direction is extremely relevant both for individual countries and for international organizations, in which Ukraine is a member. техніки для розширення кола джерел криміналістично значущої інформації, яка може бути використана у ході міжнародного розшуку.

$\begin{array}{lcr}\text { Ключові } & \text { слова: } & \text { криміналістичне } \\ \text { забезпечення, } & \text { міжнародний } & \text { розшук, } \\ \text { підозрюваний, кримінальне правопорушення. }\end{array}$

However, the study of theoretical and practical sources indicate that just legal regulation of this activity is insufficient; it requires comprehensive measures of organizational, logistical, personnel, tactical, scientific and educational support, which create conditions for the implementation of the relevant tasks.

One of the important complex forms of securing international search is forensic support. The essence of forensic support comes from the interpretation of criminal science as a science on the regularities of the mechanism of a criminal offence, the information about the criminal offense and perpetrators, the laws of collection, research, evaluation and use of evidence, and based on knowledge of these patterns special tools and methods of pre-trial investigation and prevention of criminal offenses (Piaskovskyi, 2020, p. 31).

The international search is mainly applied to persons, who are suspected (accused) of committing criminal offenses and evade serving a sentence for committing a criminal offense. That is, the activities of the international investigation are aimed at achieving the objectives of criminal proceedings, covered by the subject matter of forensic research.

Thus, purpose of the study is to formulate theoretical bases and practical recommendations for forensic support of the international search.

\section{Methodology}

In the course of the research general scientific methods were used; in particular: analysis and synthesis method, method of induction and deduction, methods of specification and summarization and method of analogy.

In particular, analysis and synthesis method and the method of induction and deduction were used to characterize the international search, the examine the features of the stages of forensic support for international search, to study the relationship between the processes of constant 
development of science and technology and the integration of the best scientific and technological progress into law enforcement.

The methods of summarization and analogy, as well as the method of specification were used to form practical recommendations based on the study of legislation, practice of international organizations and foreign countries, in order to implement positive international and improve domestic law enforcement.

Besides, specific methods of scientific research were used in this article. In particular, comparative and legal method was applied in order to compare the law of Ukraine and the provisions of international documents governing the procedure of international search and certain aspects of its forensic support.

Historical and legal method helped to reveal the content of scientific views on the interpretation of the concepts of "forensic support", "international search", as well as to trace the development of scientific views on these issues.

System and structural method was implemented for the formulation of tasks that are solved within forensic support of the international search.

The works of scientists concerning the issue under consideration were analyzed based on the method of information systematization.

The method of legal forecasting made it possible to identify the directions for the further development of scientific views and the formation of practical recommendations on the issue of forensic support of international investigation.

\section{Literature Review}

Dusheiko, Nekrasov, Matsiuk and Kompaniiets (2006, p. 33) offer in their monograph a fairly broad definition of international search. According to the authors it is a separate function of international organizations (Interpol), national justice bodies, law enforcement agencies (depending from the organization of operational and investigative activities, pre-trial investigation and international cooperation in a particular State) and is a set of operational and investigative measures and search actions carried out in two or more States.

According to Liashuk (2015, p. 298) it is a set of operational and investigative measures, search actions and administrative and verification measures coordinated by specialized international organizations or authorized bodies of States carried out in accordance with the rules of international law, national law, enshrined in the legislation on operational and investigative activities, departmental normative and legal acts, etc..

Karpov (2011, p. 11) believes that the international search is the set of operational, resource and search activities carried out at the request of specially authorized bodies, law enforcement agencies of the requested countries trough Interpol - ICPO.

In turn, "forensic support", can be described as an activity towards the creation of the conditions of preparedness and implementation of methods, tools, techniques of forensic techniques, forensic tactics and forensic methodology, based on the principles of general theory of forensics and aimed at achieving the objectives of criminal justice. The main areas of forensic support are technical-forensic, tactical-forensic and methodological-forensic (Chornous, 2020, p. 272).

The monographs by Melcher (1926) and Marcel Le Clère (1957) were among the first foreign works to address the issue of international investigation as one of the activities of the police in the area of combating crime.

The peculiarities of the regulation of the international search in the United States were studied by Smith (1960). In this regard the scientist notes, in particular, that the procedural aspects of the international search for persons are implemented on the basis of domestic regulations of the United States and international treaties (and therefore do not actually differ from the legislation of Ukraine governing this issue). Law enforcement agencies send a request to the Interpol National Central Bureau, which in turn considers it and, if the request meets all the conditions, sends it to Interpol. This organization notifies the countries where the perpetrator is likely to be hiding, after which the police conduct procedural actions to search for the person. However, the organizational and technical aspects of the exercise of the powers of the NCB of Interpol are different, which causes some difficulties in finding persons who have committed a criminal offense abroad (Smith, 1960).

However, perpetrators of criminal offenses in the United States are not always wanted internationally because of the complexity of the 


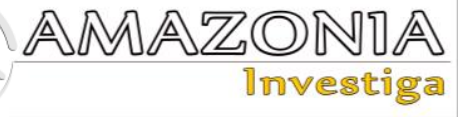

case and the desire to protect the public (mostly drug and information security cases). This is not the way to effectively investigate such cases because federal wanted notice or other information relating to the course of the investigation is transparent and publicly available. Therefore, this means of protecting society from criminal offences is highly questionable (Scott, 2000).

As Interpol's connection with US law enforcement is important, it is the NCB of Interpol that should maintain close relationships with U.S. law enforcement. To this end, Interpol NCBs operate in each State, as well as in the 11 largest US cities. Their main task is to implement the legal norms concerning the search for persons outside the United States, as well as to accept requests from foreign States to search for criminals, which are passed to the relevant law enforcement agencies for analysis and response (Warner, 1992).

\section{Results and Discussion}

The study of the provisions of the main international agreements on the fight against crime, ensuring the international search, indicates that the problem of improving the effectiveness of activities in this direction is extremely relevant for both individual countries and international organizations. Emphasis should be placed on the basic principles of forensic search in accordance with the most complex one - international level of implementation.

It should be noted that the actual international search can be applied to suspects, accused, defendants and convicted persons who are hiding from the pre-trial investigation, court, evading criminal punishment, as well as missing persons. These aspects of the international search will be explored in the article. However, in order to optimize a significant amount of theoretical material, we will mainly use the term "international search", understanding the range of persons to whom it can be applied.

Legal regulation of international search is accompanied by a number of problematic issues; the Criminal Procedure Code of Ukraine (Law No. 4651-VI, 2010) does not regulate the issue of international search, but enshrines other forms of international cooperation in criminal proceedings. Therefore, the actual international search can be described as a legal institution, which is regulated by different branches of law and at different levels - international and national ones.
According to the Criminal Procedure Code of Ukraine (Law No. 4651-VI, 2010), the main forms of international cooperation in criminal proceedings are: 1) international legal assistance in conducting procedural actions; 2) extradition of persons who have committed criminal offenses; 3) criminal proceedings in the order of adoption; 4) recognition and execution of sentences of the courts of foreign States and transfer of convicted persons.

However, studied the peculiarities of legal regulations, theoretical principles and practice of their implementation, we are convinced that the international search should be considered as a comprehensive legal institution and a separate form of international cooperation. Accordingly, international search requires forensic support at different stages of its implementation.

For example, before announcing an international search, an investigator or other legally authorized entity should collect a large amount of systematic information about the suspect (accused), which includes personal data (first name, last name and patronymic, time and place of birth, nationality, citizenship, education, marital status), place of permanent or temporary residence; place of work, type of occupation, specialty; criminal record. Detailed information about the appearance, as well as special characteristics of the person is also required. If available, fingerprints and DNA profile are provided. Data on the relatives, friends, and acquaintances is clarified and provided. Photos and other materials that can facilitate the search are attached. Information about the appearance is obtained both through the use of photo and video materials, and through the use of the technique of "verbal portrait", which is based on the information provided by witnesses and victims in criminal proceedings. This information is of forensic nature, i.e. is related to the criminal offense by causation, and / or used to detect, investigate and prevent criminal offenses.

When identifying a suspect and in case of his (her) subsequent detention by authorized officials, the relevant tactics and arrangements are used and special tactical operations are developed to ensure suddenness during direct physical detention in order to prevent escape attempts.

Forensic support under these conditions deals with the process of recording actions to detain the suspect, his (her) subsequent personal search, preparing a report and appendices to it (photo and video materials). It mainly lies in solving the 
organizational and tactical and technical and forensic principles of investigation.

Attention should be paid to the peculiarities of forensic support of the next stage of international search - the extradition of a person. According to Par. 2, Art. 541 of the Criminal Procedure Code of Ukraine (Law No. 4651-VI, 2010), extradition of the person is the transfer of the individual to the State, the competent authorities of which this person is wanted for criminal prosecution or execution of a sentence.

The essence of forensic extradition is that it involves not only the only fact, but also the set of procedural actions and organizational measures aimed at preventing attempts by the person to evade the investigation, to continue criminal activity, preservation of sources of evidentiary information, verification of circumstances that may prevent extradition.

Thus, the international search should be considered a separate legal institution, the regulation of which is complex and independent form of international cooperation in criminal proceedings and other tasks of law enforcement.

This procedural institution is specific also because it includes implementing specific procedural actions (for example, search in data banks of the States and Interpol of persons suspected of commission of a criminal offense, DNA profiles, fingerprints, carrying out interrogations, searches, requests of documents, etc.).

In particular, Leshukova (2004, pp. 16-17) comes to the conclusion that the organization of such a search includes a wider range of actions than the list provided in the relevant instructions and scientific developments. She includes in this list the following: actions to identify the wanted person in the territory or the areas, where the criminal offense was committed; collection of evidence confirming the fact that the person stays outside Ukraine; preparation of the request and additional documents; submitting such a request and appendices to it to the UkrBureau of Interpol in the manner prescribed by the relevant regulations; the decision of the General Secretariat of Interpol to declare or deny the international search; actions taken in the IOCP Member States to search for persons who have committed criminal offense; sending notifications and relevant documents on the results of the search; transfer of the wanted person to the relevant law enforcement agencies of Ukraine.
Nalyvaiko (2016, pp. 174-175) has formulated a list of covert investigative (search) actions aimed at the activities of an investigator on the search for a suspect in order to establish his (her) whereabouts: audio and video surveillance of persons, inspection and seizure of correspondence, removal of information from electronic information systems, inspection of publicly inaccessible places, housing or other property of a person; the scientist has stressed the need to carry out these actions during the search for a person.

Havryliuk, Dubyna, Danyliuk (2017) point to the actions taken in the process of international search: initiating search activities on the territory of one, several or all Interpol Member States; placing information on wanted or other persons, including citizens of Ukraine, who are not wanted, but are the members of organized criminal groups or prone to committing criminal offenses in different States in the databases of the General Secretariat of Interpol. It is important that in the latter case we are talking about the implementation of tasks to prevent criminal offenses.

Considering the issue of forensic support of the international search, we consider it necessary to explain that information is subject matter of the study for both forensics and forensic support. However, it should be noted that the source of such information is actually the person (suspected, accused, defendant, convict), who is wanted internationally. Thus, almost always such people use mobile devices, social networks, send e-mails, etc. Besides, there are video surveillance cameras in public places (stations, central streets, restaurants) that capture a person's appearance. This information is analyzed by competent actors in order to successfully solve the problems of search activities.

Forensic support for the international search lies in maximizing the use of modern advances in science and technology to expand the range of sources of forensic information that can be used in the international search. "Non-obvious" sources of trace information are also analyzed: micro-objects (traces of fibers, hair, and substances), traces of habits and smells. These are the sources of investigative information that are difficult for the wanted person to control and their use becomes the "key" to solving a complex problem.

So, let's focus on the peculiarities of the international level of search and the tasks of law enforcement agencies of Ukraine and foreign 


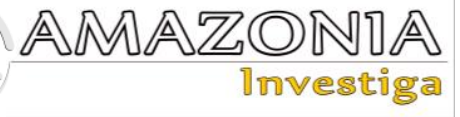

countries, international organizations in achieving the set objectives.

The practice of foreign States on international cooperation in the course of conducting search activities deserves special attention. For example, in Denmark, Germany, Iceland, Latvia, Lithuania, Norway, Finland, Sweden, Estonia, the actions carried out within international cooperation, including in the course of international search, are: the seizure of information transmitted over telecommunications networks; wiretapping; electronic surveillance; covert video surveillance; measures to identify the person (including fingerprints and photography); crossborder surveillance; cross-border prosecution of a criminal; cross-border use of agents infiltrating a criminal organization; cross-border surveillance to search for stolen cars; controlled deliveries (Kohutych 2008, pp. 53 - 54). These measures can be implemented through international cooperation during search activities, and this form of cooperation contributes to the effective solution of law enforcement problems.

Important tasks in the implementation of international search objectives are solved by the International Criminal Police Organization Interpol. Cooperation with Interpol is carried out for the purpose of conducting an international search through Interpol channels, ensuring the extradition of a person.

Interpol uses a number of tools to implement its tasks. One of them is the use of information retrieval system 1-24/7 - global telecommunications system, which is built on the latest information technology, provides quality and confidential round-the-clock direct access to information resources of the General Secretariat of Interpol, and allows information exchange between NCBs for Interpol of different States.

Interpol is equipped with a computerized Criminal Information System (ICIS), which can be used to search for a wide range of information: to identify criminals, bank accounts, names and addresses of legal entities involved in the crime. The Automated Search Facility (ASF) allows the NCBs for Interpol and operative agencies to search for certain information electronically in data banks. This system allows the transfer of images between the NCBs for Interpol of different States. Information and analytical support for Interpol's activities is provided, in particular, by Analytical Criminal Intelligence
Unit (Ortynskyi, Chornous and Pavliuk 2018, p. 256).

Forensic support for the international search activities lies in the use of Interpol databases, which contain forensic information. These are the following databases: 1 ) "persons", which include information on persons wanted for criminal offenses; persons considered missing; persons to be identified; 2) data on stolen or lost documents; 3) data bank on stolen vehicles; 4) data on stolen works of art; 5) database of DNA profiles removed from crime scenes on the territory of Interpol Member States and DNA profiles of criminals; 6) data bank of fingerprints removed from crime scenes, fingerprints of criminals, etc. The NCB for Interpol in Ukraine provides the general bank with information concerning specific wanted persons, as well as uses the information in the databanks for direct searches of persons, in particular on behalf of law enforcement agencies of other countries (Lysenko, 2016, pp. 58-62).

The forensic content of the above information is due to the fact that forensic science tools, methods and techniques should be used for its study, production, accounting and application (Chornous, 2017, pp. 273-274).

Interpol is responsible for the organization and coordination of international searches of accused persons, defendants and convicted persons evading pre-trial investigation, court, evading the serving of criminal sentences and missing persons at the request of law enforcement agencies of Ukraine and competent authorities of Interpol Member States.

Interpol arranges for handover and escort of persons concerning which the competent authorities of foreign States have decided on granting requests of the Prosecutor General's Office or the Ministry of Justice of Ukraine for extradition, temporary extradition, transit or transfer for further serving of the sentence, as well as helps to resolve a number of other tasks.

Accordingly, the actor of the international search in the country initiating the search is the relevant law enforcement agency. The subject of the search in the requested country is the law enforcement agency carrying out the relevant actions. But the implementation of the international search procedure is impossible without the participation of the Interpol, represented by the General Secretariat and the National Central Bureaus in each Member State, as well as their local units. We can also classify 
Europol, the European Police Office, which performs certain functions to facilitate the international search for criminals, as the actors of international search.

The interaction of domestic law enforcement agencies with Interpol in Ukraine is regulated by the Instruction on the use of information system of the International Criminal Police Organization - Interpol by law enforcement agencies of Ukraine (Order No. 613/380/93/228/414/510/2801/5, 2020).

According to Par. 1 of the Instruction (Order No. 613/380/93/228/414/510/2801/5, 2020), international cooperation of law enforcement agencies of Ukraine with Interpol agencies, $\mathrm{NCBs}$ of foreign States, competent bodies of foreign States and international institutions using the Interpol information system is carried out on the issues and in the forms specified by Interpol rules. Such cooperation is carried out in order to: ascertaining the whereabouts of wanted persons in order to detain, arrest them, restrict their freedom of movement and further extradition; ascertaining the whereabouts of persons or objects of interest to law enforcement agencies of Ukraine or other Interpol Member States; providing or receiving information related to the investigation of crimes, criminal history or criminal activity of persons; providing or receiving information to warn of persons, events, objects, methods of committing crimes that pose a real threat to public safety and order and may cause significant damage to property or citizens; identification of persons or unidentified corpses; conducting forensic investigations; providing or receiving information on international search. Interpol's competence in organizing international investigations includes the organization and coordination at the request of law enforcement agencies of Ukraine, competent authorities of Interpol Member States of international investigation of accused, defendants and convicted persons who are hiding from pre-trial investigation, court, evading criminal punishment and disappeared.

However, the study of both regulations and materials of practical activities indicates the need for systematic forensic support of these activities. The requests sent to the authorized unit shall indicate information that is of questionnaire nature, describes the information collected in the case that is of forensic nature (for example, a detailed description of the circumstances of the criminal offence for which the person is subjected to international search).
In order to optimize this activity, Interpol has a system of circular alerts (circulars), consisting of standardized requests for international cooperation or international warnings about threats to public safety, persons or property, issued for the purpose of: detention, arrest or restriction of freedom of movement of the suspect, accused, defendant, convicted for the purpose of extradition; ascertaining the whereabouts of the person; obtaining additional information about the person; identification of a person; information on the person's criminal activity; providing personal information.

The application of the set of measures of forensic support for the international search can ensure the achievement of the objectives of criminal proceedings, as well as effective implementation of law enforcement activities in Ukraine in accordance with the best international standards.

\section{Conclusion}

The international search should be considered a separate legal institution and an independent form of international cooperation in criminal proceedings and law enforcement.

The process of international search is carried out in the following forms: preparation and sending of initiative requests abroad; preparation and sending of answers to the inquiries of foreign law enforcement agencies; exchange of intelligence, reference and criminological information on preparation and commission of criminal offenses and persons involved, as well as archival and, in some cases, procedural information; exchange of work experience, legislative and other normative acts, educational and methodical literature on the activities of law enforcement agencies; exchange of scientific, technical and other information on the fight against crime.

Forensic support in this context is to create conditions for the preparedness and implementation of methods, tools, techniques of forensics in order to solve the problems of international search.

International search is implemented according to certain stages and at each stage there is a need to apply various measures of forensic support, in particular:

1) collecting information on the person, in respect of whom the international search will be announced (biographical data, place of residence, description of the person's appearance, special features, photo and 


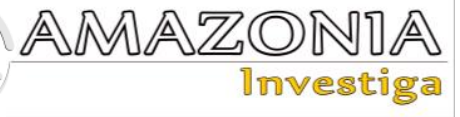

video recordings, fingerprints, DNA profile, etc.). This information is forensic one, i.e. is related to the criminal offense by causation, and / or used to detect, investigate the prevention of criminal offenses;

2) ascertaining the suspect's whereabouts and his (her) subsequent detention by authorized officials, in the course of which special tactical operations shall be used in order to ensure suddenness during direct physical detention and prevent escape attempts. Besides, forensic support under these conditions concerns the process of recording actions to detain the suspect, his (her) subsequent personal search, preparation a report and appendices to it (photo and video materials). Forensic support mainly lies in solving organizational and tactical and technical and forensic tasks under these conditions;

3) the essence of forensic support, under terms of the subsequent extradition of a person, is that latter involves not only the fact of extradition, but also a set of procedural actions and organizational measures to prevent attempts to evade investigation, preservation of sources of evidentiary information, etc.

4) important tasks in the implementation of international search objectives are solved by the International Criminal Police Organization - Interpol. Cooperation with Interpol is carried out for the purpose of conducting an international search through Interpol channels, ensuring the extradition of the person. Forensic support for the international search activities lies in the use of Interpol databases, which contain forensic information. These are databases of persons wanted for criminal offenses; persons considered missing; persons to be identified; data bank on stolen vehicles; database of DNA profiles removed from crime scenes in the territory of Interpol Member States and DNA profiles of criminals; database of fingerprints removed from crime scenes, fingerprints of criminals, etc. The forensic content of the above information is due to the fact that forensic science tools, methods and techniques should be used for its study, production, accounting and application.

Forensic support for the international search lies in maximizing the use of modern advances in science and technology to expand the range of sources of forensic information that can be applied in the international search. Besides, "non-obvious" sources of trace information are analyzed: micro-objects (traces of fibers, hair, substances), traces of habits and smells. These are the sources of information that are difficult for the wanted person to control, so their use becomes the "key" that allows to solve complex problems.

The study makes it possible to form a number of theoretical conclusions and scientific and practical recommendations for optimizing the international search by national law enforcement agencies using international law enforcement institutions and to identify promising areas of research on selected issues for the future.

\section{References}

Chornous, Yu. (2017). Forensic support for the investigation of crimes: a monograph. Vinnytsia: Nilan-LTD.

http://elar.naiau.kiev.ua/jspui/bitstream/1234567 89/16029/1/\%D0\%A7\%D0\%9E\%D0\%A0\%D0 \%9D\%D0\%9E\%D0\%A3\%D0\%A1\%20\%D0\% 9A\%D1\%80\%D0\%B8\%D0\%BC\%20\%D0\%B7 $\% \mathrm{D} 0 \% \mathrm{~B} 0 \% \mathrm{D} 0 \% \mathrm{~B} 1 \% \mathrm{D} 0 \% \mathrm{~B} 5 \% \mathrm{D} 0 \% \mathrm{~B} 7 \% 20 \%$ D1\%80\%D0\%BE\%D0\%B7\%D1\%81\%D0\%BB \%20\%D0\%B7\%D0\%BB\%D0\%BE\%D1\%87\% D0\%B8\%D0\%BD\%20\%D0\%905.pdf

Chornous, Yu. (2020). Topical issues of investigation and trial by an International criminal court of cases of international crimes. Journal of the National Academy of Legal Sciences of Ukraine, 27(4), pp. 268 -281.

Dusheiko, H., Nekrasov, V., Matsiuk, V. and Kompaniiets, D. (2006). International search: theory and practice: monograph. Kyiv: KNT. https://www.yakaboo.ua/mizhnarodnij-rozshukteorija-ta-praktika.html

Havryliuk,V., Dubyna, V., \& Danyliuk, M. (2017). Current aspects of international cooperation between the internal affairs agencies of Ukraine to combat trafficking in persons: a guide. Kyiv: Tsifra. https://www.osce.org/files/f/documents/2/3/758 92.pdf

Karpov, O. (2011). The use of opportunities of international European organizations in the search for criminals (PhD Dissertation) National Academy of the Internal Affairs of Ukraine.

Khiyavi, A., \& Shamloo, B. (2018). The globalization of criminal law focuses on organized crime. Amazonia Investiga, 7(12), 215-225. Retrieved from https://amazoniainvestiga.info/index.php/amazo nia/article/view/593

Kohutych, I. (2008). Forensic knowledge, their essence and the need to broaden the scope of use: monograph. Lviv: Triada Plus. https://scholar.google.com.ua/scholar?hl=ru\&as _sdt $=0,5 \&$ cluster $=11657573817837348759$ 
Law No. 4651-VI. Official Gazette of the Verkhovna Rada of Ukraine, Kyiv, Ukraine, April 18, 2010. https://zakon.rada.gov.ua/laws/show/4651-

17\#Text

Le Clère, M. (1957). Histoire de la police: Par Marcel Le Clère. France: Presses Universitaires de France. [History of the police: By Marcel Le Clère. France: Presses Universitaires de France.] Leshukova, I. (2004). Procedural features of international cooperation of Ukrainian law enforcement in crime investigation. (PhD Dissertation) National University of the Internal Affairs of Ukraine.

Liashuk, O. (2015). "Features of the initial stage of the international wanted of persons who committed a criminal offense". In: Bulletin of Law University of Kyiv, Num. 3, pp. 297 - 300. http://ir.nusta.edu.ua/jspui/bitstream/123456789 /2294/1/2189_IR.PDF

Lysenko, O. (2016). Forensic support for the search of fugitives from pre-trial investigation and trial (PhD Dissertation). Taras Shevchenko National University of Kyiv. http://scc.univ.kiev.ua/upload/iblock/0a5/dis_Ly senko\%20O.V..pdf

Melcher, K. (1926). Die Geschichte der Polizei [The story of the pólice]. Berlin: Gersbach \& Sohn.

Nalyvaiko, Ye. (2016). "Regarding detection of a suspect whose whereabouts are unknown". In: Scientific Bulletin of the National Academy of the General Prisecutor's Office of Ukraine, 3, pp. 170-176. http://www.chasopysnapu.gp.gov.ua/ua/pdf/112016/nalivajko.pdf

Order No. 613/380/93/228/414/510/2801/5. Official Gazette of the Verkhovna Rada of Ukraine, Kyiv, Ukraine, August 17, 2020. https://zakon.rada.gov.ua/laws/show/z084920\#Text

Ortynskyi, V., Chornous, Yu. and Pavliuk, N. (2018). International cooperation in financial fraud investigation. Baltic Journal of Economic Studies, 4(4), pp. $252-258$.

Piaskovskyi, V., ed. (2020). Forensics: a textbook: 2nd ed. Kyiv: Pravo. https://pravoizdat.com.ua/image/data/Files/816/3_Kriminalis tika_pidruchnik_2020_vnutri.pdf

Scott, M. (2000). Problem-Oriented Policing: Reflections on the First 20 Years. Washington D.C.: U.S. Department of Justice, Office of Community, Oriented Policing Services https://www.researchgate.net/publication/26543 3728_Problem-

Oriented_Policing_Reflections_on_the_First_20 _Years

Smith, B. (1960). Police Systems in United State. New-York: Harper \& Brothers.

Warner, J. (1992). Federal Jobs in Law Enforcement. An official website of the United States government, Department of Justice. https://www.ojp.gov/ncjrs/virtual-

library/abstracts/federal-jobs-law-enforcement 